\title{
Recent advancement in EUS-guided fine needle sampling
}

\author{
Pujan Kandel $^{1} \cdot$ Michael B. Wallace $^{1}$
}

Received: 13 November 2018/Accepted: 21 January 2019/Published online: 26 February 2019

(C) The Author(s) 2019

\begin{abstract}
EUS-guided tissue acquisition technique plays an essential role for evaluation of gastrointestinal tumors. Several components affect the yield of EUS-guided tissue acquisition outcomes such as sampling techniques, use of ROSE (rapid onsite evaluation), training and experience, and needle designs. In this review we discuss advancement in EUS-guided fine needle sampling.
\end{abstract}

Keywords Endoscopic ultrasound · Fine needle aspiration · Fine needle biopsy

$\begin{array}{ll}\text { Abbreviation } & \\ \text { EUS } & \text { Endoscopic ultrasound } \\ \text { FNA } & \text { Fine needle aspiration } \\ \text { FNB } & \text { Fine needle biopsy } \\ \text { EUS-FNA } & \begin{array}{l}\text { Endoscopic ultrasound fine needle } \\ \text { aspiration }\end{array} \\ \text { EUS-FNB } & \begin{array}{l}\text { Endoscopic ultrasound fine needle biopsy } \\ \text { RCT }\end{array} \\ \text { Randomized controlled trial } \\ \text { FFPE } & \text { Formalin fixed, paraffin-embedded } \\ \text { GIST } & \text { Gastrointestinal Stromal tumor } \\ \text { PDXs } & \text { Patient-derived xenografts } \\ \text { EUS- } & \text { EUS-guided through-the-needle forceps } \\ \text { TTNFB } & \text { biopsy } \\ \text { ROSE } & \text { Rapid onsite evaluation }\end{array}$

Michael B. Wallace

wallace.michael@mayo.edu

Pujan Kandel

kandel.pujan@mayo.edu

1 Department of Gastroenterology and Hepatology, Mayo Clinic Florida, 4500 San Pablo Road, Jacksonville, FL 32224. USA

\section{Introduction}

Endoscopic ultrasound is one of the important tools for evaluation of gastrointestinal tumors and areas around the gastrointestinal tract. Tissue procurement techniques and tools have evolved significantly over a period of 25 years. Endoscopic ultrasound-guided fine needle aspiration (EUS-FNA) and fine needle biopsy (EUS-FNB) are useful for screening, pathological diagnosis, and staging such as pancreaticobiliary, esophageal, gastric, rectal, and lung diseases [1]. The main end results of EUS-guided fine needle samplings include adverse events, accuracy, histology, and diagnostic yield [2]. EUS-guided tissue sampling is relatively safe and accurate [3]. There are several factors that affect the outcome of this technique such as lesion location and characteristics, experience of endoscopist, EUS fine needle aspiration (FNA) versus fine needle biopsy (FNB), needle gauge, sampling technique, and the presence of onsite cytotechnician [4]. One of the main challenges associated with this technique is low diagnostic yield (false-negative diagnosis) which ranges up to $4 \%-45 \%$ in solid pancreatic mass, $21 \%-53 \%$ in pancreatic cystic neoplasms, and 6\%-14\% in lymph nodes [5]. The main objective of this review is to focus on the recent advancement in EUS-guided tissue acquisition techniques, needle technologies, and its clinical applications.

\section{Indication of EUS-FNA}

EUS-FNA is useful technique for diagnosis and staging of lesions in and around the proximity of gastrointestinal tract [6-11]. It is superior and effective compared to CT-guided or ultrasound-guided biopsy of lesions [12]. For diagnosis of solid pancreatic lesions, sensitivity and specificity of 
EUS-FNA is $85 \%-89 \%$ and $96 \%-99 \%[13,14]$, whereas for pancreatic cystic lesions it is $54 \%$ and $93 \%$ [15]. The lower sensitivity for diagnosis of cystic lesions is often due to sampling errors, insufficient aspirates, or may be due to different approaches (transgastric or transduodenal) $[16,17]$. EUS-FNA is useful technique for pathological diagnosis of abdominal and mediastinal lymph nodes [18]. Tissue procurement from lymph nodes is quite challenging especially in cases of hematologic malignancies such as lymphoproliferative disorders which require adequate tissue to perform immunophenotyping and describe histological architecture. Some studies demonstrated that accuracy of FNA for abnormal lymphocytes is around 70\%-90\% [19-25]. For mediastinal lymph nodes sensitivity and specificity of EUS-FNA are $88 \%$ and $96 \%$ vs $84 \%$ vs $88 \%$ with EUS imaging alone [26]. Thus, EUSFNA is safer and less invasive compared to mediastinoscopy and is the first choice for small cell cancer staging when combined with bronchoscopy [27, 28]. In addition EUS-FNA is useful for evaluation of sub epithelial lesions, nodal staging of esophageal cancer, liver lesion, and malignant biliary structures [29-31]. Summary of diagnostic values EUS-FNA for different lesions are illustrated below (Table 1). Optimal tissue acquisition from lesions depends on various factors such as needle FNA needle sizes and gauges, fine needle biopsy (FNB) needles, presence of cytotechnologists for rapid onsite evaluation (ROSE), expertise of endoscopist, and tissue handling techniques [32]. American Society for Gastrointestinal Endoscopy (ASGE) guidelines recommend 150 supervised EUS procedures of which 75 should involve pancreaticobiliary system with 50 of them include EUS-FNA [33].
However, recent metaanalysis emphasizes on no clear number of EUS procedures [34] but the success of endoscopist depends on performing EUS at high volume center as procedure is greatly operator dependent [35].

\section{Advancement in EUS-guided FNA and FNB}

\section{Needle gauge and type}

For last 2 decades EUS-FNA has been a mainstay for sampling of tissue from pancreas, lymph nodes, liver, and subepithelial lesions. Currently 3 types of EUS-FNA needles are available in market for clinical use: 19G, 22G, and 25G. Several studies have been published comparing $22 \mathrm{G}$ vs $25 \mathrm{G}$ needles on lymph nodes and solid lesions [36-45]. Most studies showed similar diagnostic yield of malignancy between groups. However, result of the two metaanalyses comparing $25 \mathrm{G}$ vs $22 \mathrm{G}$ showed that $25 \mathrm{G}$ is more sensitive than $22 \mathrm{G}$ for diagnosing pancreatic malignancy with overall adequate specimen obtained with 25 -gauge needle [46, 47]. Therefore, "the use of $25 G$ needle is associated with a higher diagnostic yield compared with a $22 G$ needle in patients undergoing EUS-FNA of pancreatic masses" [4]. In addition RCT (randomized controlled trials) have shown no significant difference in diagnostic yield malignancy using $19 \mathrm{G}$ needle compared with the $22 \mathrm{G} / 25 \mathrm{G}$ needle [48-50]. EUS-FNA technique is relatively safe with few adverse events such as pain, pancreatitis, bleeding, and infections [51] with an morbidity of $0.98 \%$. Pancreatitis rate is about $0.44 \%$ and overall mortality is $0.02 \%$ [52].
Table 1 Diagnostic values for EUS-FNA for different lesions

\begin{tabular}{llll}
\hline Lesions & Sensitivity & Specificity & Accuracy \\
\hline Malignant biliary strictures & & & - \\
Navaneethan et al. (2015) [117] & $66 \%$ & $88 \%$ & - \\
Sadeghi et al. (2016) [116] & $100 \%$ & $80 \%$ & $80 \%$ \\
Subepithelial lesions (upper and lower GI tract) & & $93 \%$ \\
Turhan et al. (2011) [115] & $82.9 \%$ & - & \\
Larghi et al. (2014) [114] & - & & - \\
Liver lesions & & - & - \\
Tenberge et al. (2002) [31] & - & $99 \%$ \\
Solid pancreatic lesions & & $99.3 \%$ & - \\
Hebert-Magee et al. (2013) [113] & $88.6 \%$ & $98 \%$ & - \\
Hewitt MJ et al. (2012) [13] & $85 \%$ & $95.8 \%$ & \\
Puli SR et al. (2013) [14] & $86.8 \%$ & $93 \%$ & \\
Cystic Pancreatic lesions & & $90.6 \%$ & - \\
Thronton et al. (2013) [15] & $54 \%$ & $96 \%$ & \\
Suzuki et al. (2014) [112] & $64.8 \%$ & & \\
Mediastinal lymph nodes & & $88 \%$ &
\end{tabular}


It is often difficult to diagnose with FNA cytology alone in conditions such as autoimmune pancreatitis, lymphoma, and well differentiated adenocarcinoma where histology with preserved tissue architecture is important. Therefore, fine needle biopsy (FNB) is valuable as it provides wellpreserved quality tissue samples. Quick-Core (Cook Medical, Limerick, Ireland) was the first FNB needle (also called Tru-Cut core biopsy needle) introduced in market. This $19 \mathrm{G}$ needle had an ability to procure large core tissue with a diagnostic yield ranging from 52 to $95 \%$ [49, 53-64]. Despite acquisition of large core tissue, it was later removed from marketplace due to lack of its flexibility, availability in only 19-gauge platform, and difficult access through transduodenal route. In addition QuickCore did not improve diagnostic yield significantly over FNA. This was later replaced by new needle called ProCore (Echo Tip ProCore [ETP], Cook Medical, Limerick, Ireland) with reverse bevel design, Fig. 1. This needle is available in all seizes $19 \mathrm{~g}, 22 \mathrm{~g}$, and $25 \mathrm{~g}$. The flexibility of this needle allows access through stomach and duodenum without difficulties. Two RCTs have demonstrated similar diagnostic yield of malignancy for FNB and FNA $[65,66]$. One recent meta-analysis included nine studies including retrospective, RCTs, and prospective studies [67]. There was no significant difference between ProCore and standard FNA needles in terms of diagnostic adequacy ( $78 \%$ vs $77 \%$ ), accuracy ( $86 \%$ vs $86 \%$ ), and core specimen procurement ( $78 \%$ vs $77 \%$ ) but mean number of passes was significantly lower in ProCore (mean difference 1.2; $p<0.01)$.

In over past 2-3 years, there have been significant paradigm changes in tip of EUS-FNB needle designs. Two FNB needles: one with fork-tip design with two leading sharp tips on the opposite side of the lumen to improve the tissue capture (SharkCore, Medtronic, Minneapolis, Minn.), Fig. 2 and another with three symmetric cutting

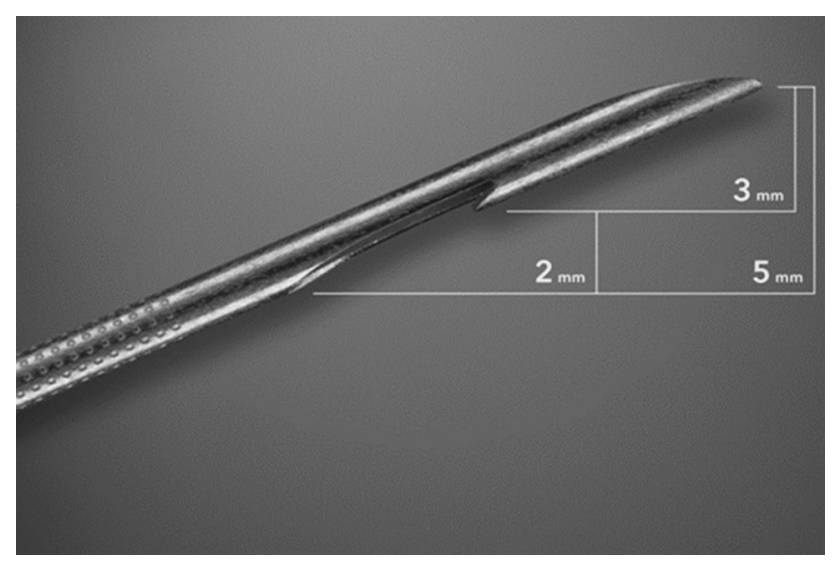

Fig. 1 Image of EchoTip ProCore needle tip (22-gauge) showing the reverse bevel that promotes the procuring of core tissue sample from the target lesion (adapted from Dwyer et al. (2016), with permission) edges (Acquire, Boston Scientific Corp, Natick, Mass.), Fig. 3 have been introduced in marketplace. Several studies have been published since then and results have demonstrated significant performance in terms of diagnostic yield and histology yield [68-73] for both the needles. In one randomized trial 22-gauge Franseen and forktip needles in sampling of solid pancreatic masses were reported. The main outcomes of the study were tumor morphology and histologic adequacy. A total of 50 patients were included in whom sampling was performed using both the needles with the order randomized. Results from this trial showed comparable diagnostic yield $(96 \%$ vs $92 \%, p=0.32)$ and diagnostic adequacy with ROSE $(94 \%$ vs $96 \%, p=.32$ ) between Franseen and fork-tip needles. In addition there was no statistically significant difference in terms of tissue quality or quantity, total tissue obtained, total tumor tissue, and the desmoplastic fibrosis yield by the two needles [74]. However, in another retrospective study, diagnostic yield was significantly lower in Franseen needle compared to the fork-tip needle $(63 \%$ vs $77 \%$, $p=0.2$ ). In subgroup analysis taking account of only solid pancreatic masses, lower yield was reported with Franseen needle compared to fork-tip needle $(64 \%$ vs $85 \%$, $p=0.01)$. Therefore, it is more important to have larger multicenter randomized trials to address the fine discrepancies in new FNB needles [75].

Published literatures have demonstrated that FNB is superior to provide adequate histological tissue compared to FNA and may save cost associated with ROSE but the questions still remain: how many dedicated passes are required for different lesions such as gastrointestinal stromal tumor (GIST), solid pancreatic tumor, etc., if to replace ROSE? How safe is FNB? What is the ideal technique? Thus, there is still need of multicenter studies to address these subtle issues.

\section{EUS-guided tissue acquisition technique}

\section{ROSE (rapid onsite evaluation)}

The main objectives of the ROSE are to provide real time feedback during endoscopy regarding the content and adequacy of specimen, to minimize the number of passes, to decrease inadequate samples, and to increase efficiency of procedure, Fig. 4. In one retrospective study EUS-guided FNA with or without ROSE was compared for sampling of pancreatic mass. Results showed that EUS-FNA with ROSE yielded greater sensitivity (96\% vs $78 \%$ ) and fewer insufficient samples (1\% vs $12.6 \%$ ) with less number of passes [76]. However, results from recent multicenter randomized controlled trial (RCT) showed similar diagnostic yield of malignancy and proportion of inadequate 
Fig. 2 The 22-gauge tip of fork-tip needle with a second tip at opposite side of the lumen (adapted from Kandel et al. (2016), with permission)
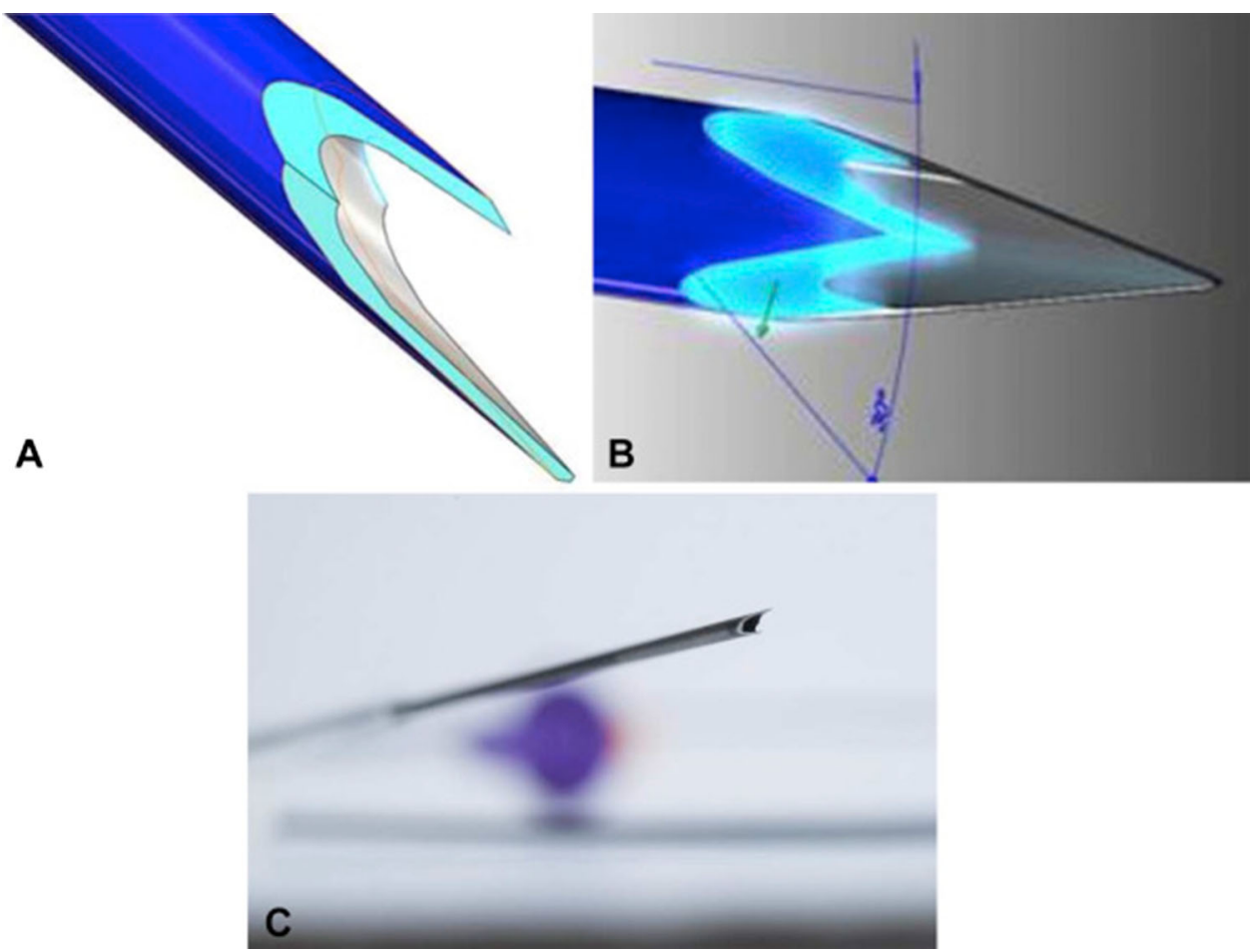

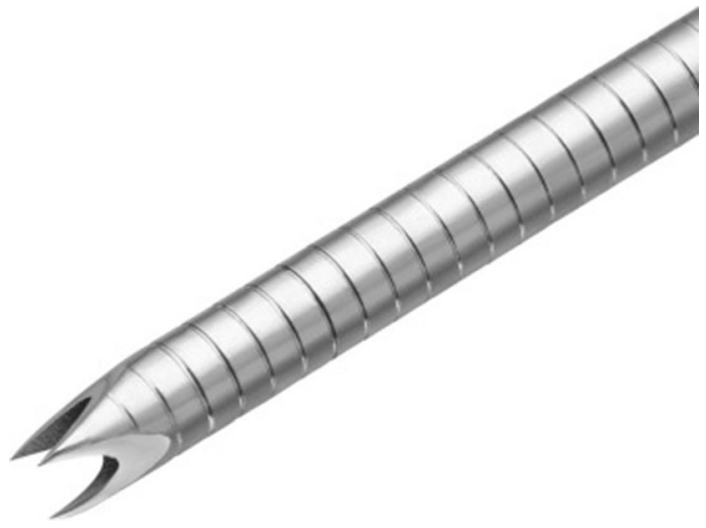

Fig. 3 The tip of 22-gauge Franseen needle design with a crownshaped containing 3 symmetric planes (adapted from Bang et al. (2018), with permission)

samples when sampling of EUS-FNA of pancreatic masses with and without ROSE. Although the EUS-FNA with ROSE arm required fewer passes, the diagnostic and cytologic yield, adverse events, total procedure time, accuracy, and number of repeat procedures were similar between two groups [77].

With the arrival of new FNB needles, ROSE has less significant impact on diagnostic yield [3, 78-80]. Use of FNB may eliminate ROSE as dedicated core tissue could be obtained with less number of passes. However, in centers with low adequacy rate $(<90 \%)$ and less experienced endoscopist, ROSE may have some substantial role [81].

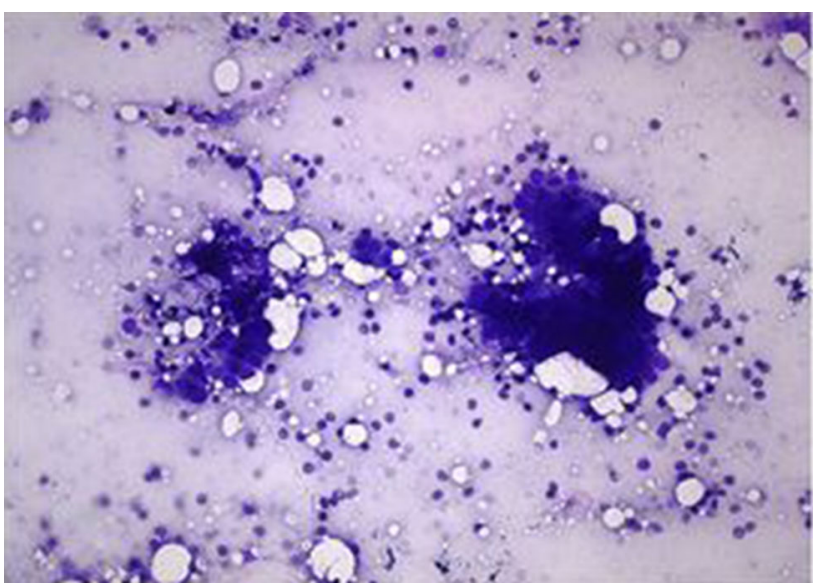

Fig. 4 On-site cytological evaluation of pancreatic sample obtained by EUS-FNA supporting the diagnosis of pancreatic adenocarcinoma (adapted from Iglesias-Garcia et al. (2011), with permission)

\section{Stylet and suction use, fanning technique, capillary/ slow pull, and wet suction technique}

The main aim of using stylet is to prevent blockade lumen of needle as it passes though the gastrointestinal wall. Studies have reported similar diagnostic yield and specimen adequacy with and without stylet [82-84]. In one study flushing of air slowly was superior than insertion of stylet second time to aspirate the samples form solid pancreatic mass [85]. Use of suction yielded higher cellularity, accuracy, and diagnostic yield. 
Fanning technique is usually utilized for acquisition of more tissue. One of the studies demonstrated that fanning technique yielded more tissue with fewer number of passes compared to standard technique [86].

Another technique called capillary/slow pull technique is usually utilized to increase aspiration of tissue as it creates negative pressure as stylet is slowly withdrawn during FNA passes. Result from one study demonstrated that adequate and good samples were obtained with capillary technique. However, malignancy yield was similar between suction and capillary technique (90\% vs $90 \%$, $p=1.00)$ [86].

In wet suction technique, air is replaced with saline. Whole idea of this technique to acquire more tissue during EUS-FNA passes. In one RCT wet suction yielded more tissue with higher cellularity compared to standard technique [87], Fig. 5a, b.

\section{Confocal laser endomicroscopy (CLE) during EUS- FNA}

Confocal laser endomicroscopy is one of the novel imaging technologies that allows microscopic visualization of the mucosal surface epithelium. Optical biopsy at realtime may further improve the diagnostic yield by reducing the sampling error. In addition this may provide the realtime feedback at the time of procedure when onsite cytologist is not available. Needle-based confocal laser endomicroscopy (nCLE) was initially studied in the rat liver and porcine model $[88,89]$ but the use of this prototype in human solid organs such as pancreas and lymph nodes has been started recently, Fig. 6. This technology involves passage of miniCLE probe through 19G during EUS-FNA and tissue level can be pictured at realtime. Some studies demonstrated feasibility and safety of nCLE in solid organs [90-92]. In one prospective study, reproducibility and diagnostic value of nCLE for solid lesions were evaluated. Results from this study demonstrated that diagnostic values and interobserver agreement between experts for nCLE parameter were poor [93]. The main limitation of this technology is heterogenicity in histology, interobserver variability, reproducibility, need of pathologists and endoscopists for better interpretation, image quality, and sampling error [94]. Further training and research are needed for applicability in realtime practice.

\section{EUS-guided needle forceps biopsy}

EUS-guided fine needle aspiration is important for cytological diagnosis. Advancement in needle technologies has improved yield of EUS sampling benefiting for both cytological and histological analysis. EUS-guided fine needle forceps biopsy technique was initially started in porcine model [95] which involved the use of small caliber
Fig. 5 Demonstrating wet suction technique preparation with saline solution (a), loading suction syringe in locked position (b) and column of saline solution moving into the suction syringe as FNA is performed (adapted from Attam et al. (2015), with permission)

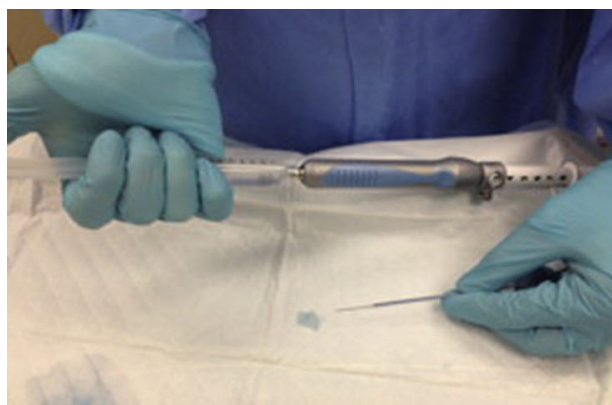

A

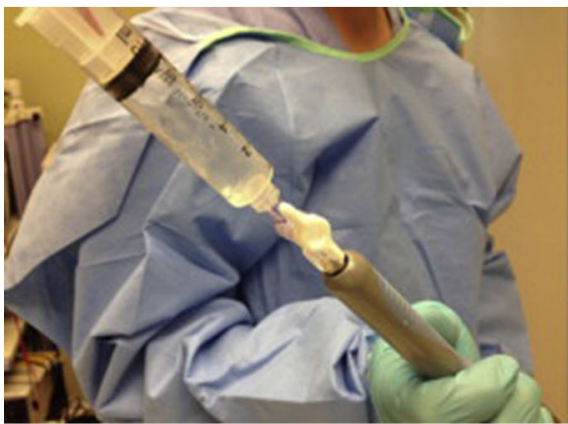

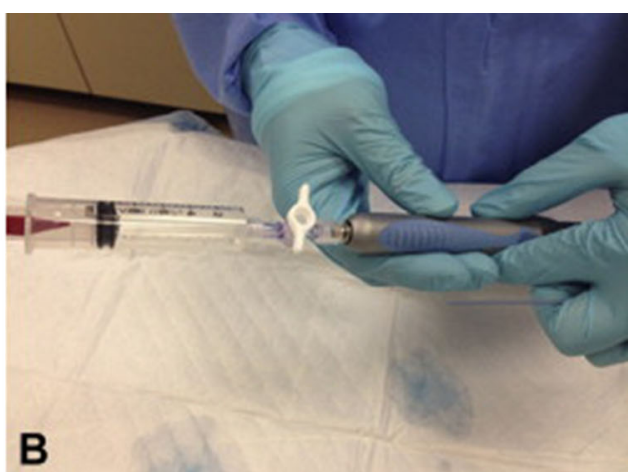

A

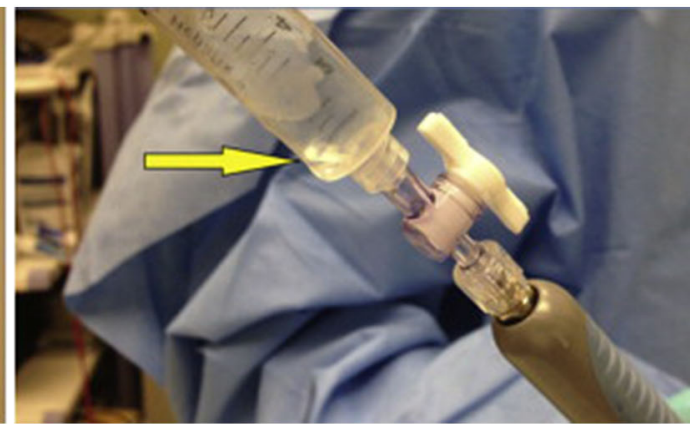

B 

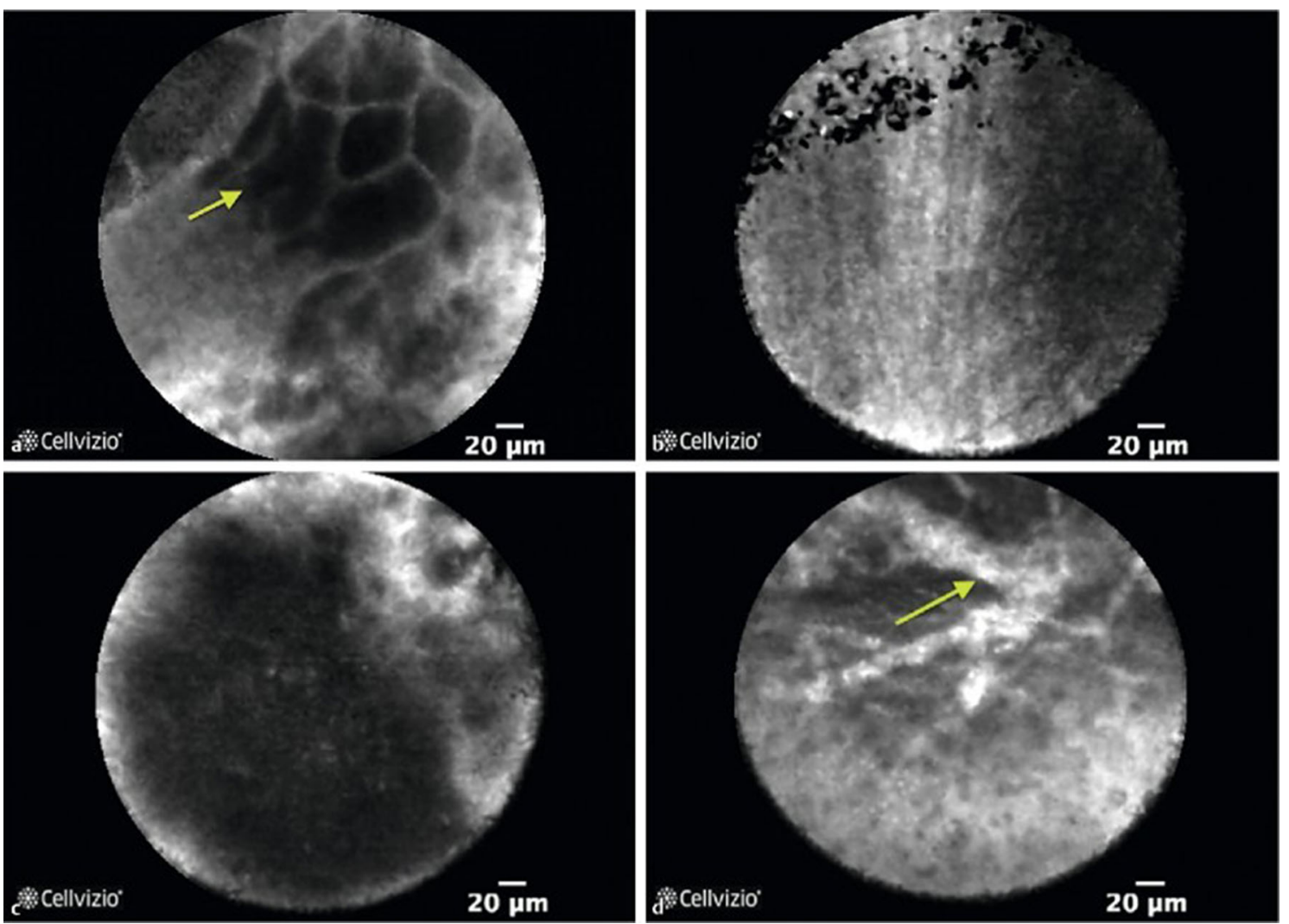

Fig. 6 Needle-based confocal laser endomicroscopy (nCLE) images of benign and pancreatic ductal adenocarcinoma lesions. [Benign lesions: a showing normal acinar cells, b-showing fine white fibrous band representing a fibrotic tissue. Pancreatic ductal adenocarcinoma:

biopsy forceps through 19-gauge FNA needle. In one retrospective study safety and efficiency of EUS-guided through-the-needle forceps biopsy (EUS-TTNFB) were studied. Results from this study demonstrated that EUSTTNFB was feasible and safe, and provided additional tissue for histological analysis, Fig. 7. No adverse events were reported. Macroscopic core tissue was obtained at a rate of $71 \%$ per pass [96].

In addition to solid organs, this novel tissue procurement technique has also been studied in pancreas cystic lesions. Distinguishing the cyst lesions appropriately may help in its management. Cystic lesions that represent diagnostic challenge can be better evaluated histologically with the help of EUS-guided biopsy of the pancreatic cystic walls. Results from one case series demonstrated that needle biopsy forceps was useful in distinguishing the nature of the cyst and stratify their management [97]. Another multicenter retrospective study also evaluated the utility of this technique in evaluation of cystic lesions. The technical and clinical success rate of this technique was found to be $85.7 \%$ and $71.4 \%$. Adverse events were observed only in $10.7 \%$ of cases [98].

c- showing dark aggregates $>40 \mu \mathrm{m}$, d- showing dilated vessels with fluorescein leakage] Adapted from Karstensen et al. (2018), with permission

Results from early studies have demonstrated that the use of EUS-guided fine needle biopsy forceps is feasible with reasonable success rates. Multicenter prospective studies are needed to determine its wide spread use in clinical practice compared to other EUS-guided sampling techniques.

\section{EUS-guided sampling in precision therapy}

Precision therapy means providing an individualized management to patient with the use of genomic information [99]. EUS-guided sampling plays a significant role in targeting gastrointestinal cancers in which tissue can be utilized for genomic analysis. This approach increases the therapeutic goal of chemotherapy and reduces side effects associated with chemotherapeutic drug [100]. Studies have reported that cytologic samples obtained by EUS-FNA are an excellent source for genetic analysis [101-105]. However, for years; formalin fixed, paraffin-embedded (FFPE) tissue blocks obtained from surgical samples have been used for genomic analysis.

Recent advancement in needle designs has improved the ability to obtain core biopsies that could be utilized for whole exome sequencing and additional genomic analysis. 
Fig. 7 Small biopsy forceps through 19-gauge needle (adapted from Nakai et al. (2016), with permission)
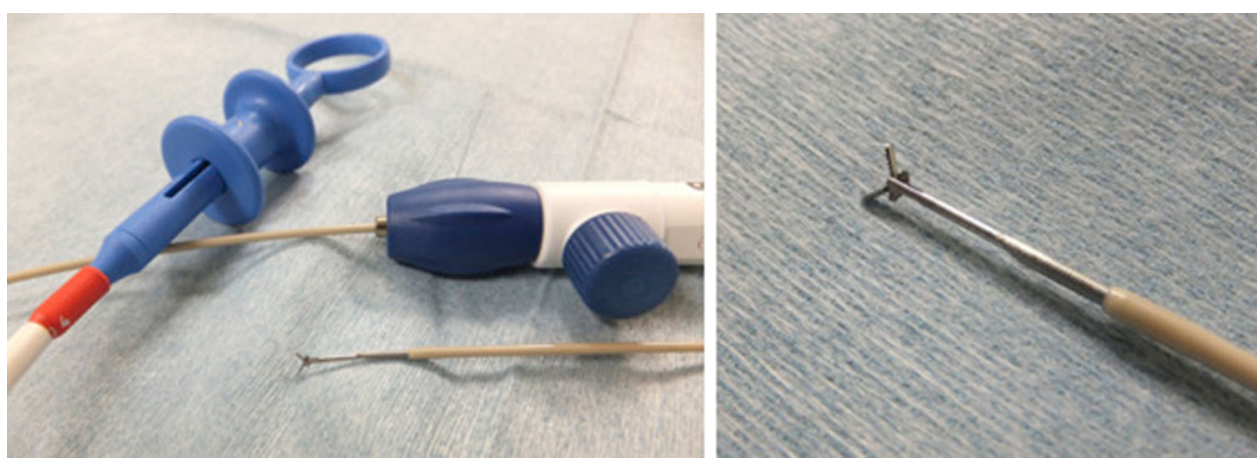

Development of tumor models such as organoid and xenograft has been possible with core biopsies sample which can be used for in vitro drug testing. Result from one study demonstrated that successful organoid creation was possible in $85 \%$ of patients with pancreas cancer [106].

Patient-derived xenografts (PDXs) is created by transmitting the resected tumor tissue from surgery to an immunocompromised host to stimulate the human biology in vivo [100]. This model provides important information on tumor biology that could be utilized for evaluation of different cancers and evaluation of chemotherapeutic drugs [107]. PDXs models can be developed with the use of EUS-FNB technique but delay in engraftment may limit its value in real time management [108].

Newer FNB needle designs have demonstrated adequate core tissue procurement with fewer numbers of passes $[109,110]$. More DNA can be extracted from the tumor tissue which could be utilized for full genomic analysis. In one ongoing study by Kandel et al. demonstrated that $74 \%$ of EUS-FNB samples of pancreatic cancer were adequate for whole exome sequencing compared to $54 \%$ of EUSFNA samples [111]. Therefore, newer generation needles may be helpful in the era of precision medicine especially in patients with pancreas cancer.

\section{Conclusion}

Advancement in EUS-guided tissue sampling techniques and development of new needle designs that have improved the diagnostic yield of solid lesions. This innovation in EUS has also opened the door for early diagnosis and precision therapy in the management of cancer patients.

Open Access This article is distributed under the terms of the Creative Commons Attribution 4.0 International License (http://crea tivecommons.org/licenses/by/4.0/), which permits unrestricted use, distribution, and reproduction in any medium, provided you give appropriate credit to the original author(s) and the source, provide a link to the Creative Commons license, and indicate if changes were made.

\section{References}

1. Kandel P, Wallace MB. Optimizing endoscopic ultrasound guided tissue sampling of the pancreas. JOP J Pancreas. 2016;17:160-5.

2. Early DS, Ben-Menachem T, Decker GA, et al. Aproppiate use of gastrointestinal endoscopy. Gastrointest Endosc. 2012;75:1127-31.

3. Keswani RN, Krishnan K, Wani S, et al. Addition of endoscopic ultrasound (EUS)-guided fine needle aspiration and on-site cytology to EUS-guided fine needle biopsy increases procedure time but not diagnostic accuracy. Clin Endosc. 2014;47:242-7.

4. Wani S, Muthusamy VR, Komanduri S. EUS-guided tissue acquisition: an evidence-based approach (with videos). Gastrointest Endosc. 2014;80(939-959):e937.

5. Fujii LL, Levy MJ. Pitfalls in EUS FNA. Gastrointest Endosc Clin N Am. 2014;24:125-42.

6. Alomari AK, Ustun B, Aslanian HR, et al. Endoscopic ultrasound-guided fine-needle aspiration diagnosis of secondary tumors involving the pancreas: an institution's experience. Cyto J. 2016;13:1.

7. Philipper M, Hollerbach S, Gabbert HE, et al. Prospective comparison of endoscopic ultrasound-guided fine-needle aspiration and surgical histology in upper gastrointestinal submucosal tumors. Endoscopy. 2010;42:300-5.

8. Patil R, Ona MA, Papafragkakis C, et al. Endoscopic ultrasoundguided fine-needle aspiration in the diagnosis of adrenal lesions. Ann Gastroenterol. 2016;29:307-11.

9. Levy MJ, Abu Dayyeh BK, Fujii LL, et al. Detection of peritoneal carcinomatosis by EUS fine-needle aspiration: impact on staging and resectability (with videos). Gastrointest Endosc. 2015;81:1215-24.

10. Levy MJ, Gleeson FC, Zhang L. Endoscopic ultrasound fineneedle aspiration detection of extravascular migratory metastasis from a remotely located pancreatic cancer. Clin Gastroenterol Hepatol. 2009;7:246-8.

11. Dumonceau JM, Deprez PH, Jenssen C, et al. Indications, results, and clinical impact of endoscopic ultrasound (EUS)guided sampling in gastroenterology: european society of gastrointestinal endoscopy (ESGE) clinical guideline-updated January 2017. Endoscopy. 2017;49:695-714.

12. Horwhat JD, Paulson EK, McGrath $\mathrm{K}$, et al. A randomized comparison of EUS-guided FNA versus CT or US-guided FNA for the evaluation of pancreatic mass lesions. Gastrointest Endosc. 2006;63:966-75.

13. Hewitt MJ, McPhail MJ, Possamai L, et al. EUS-guided FNA for diagnosis of solid pancreatic neoplasms: a meta-analysis. Gastrointest Endosc. 2012;75:319-31.

14. Puli SR, Bechtold ML, Buxbaum JL, et al. How good is endoscopic ultrasound-guided fine-needle aspiration in diagnosing 
the correct etiology for a solid pancreatic mass?: a meta-analysis and systematic review. Pancreas. 2013;42:20-6.

15. Thornton GD, McPhail MJ, Nayagam S, et al. Endoscopic ultrasound guided fine needle aspiration for the diagnosis of pancreatic cystic neoplasms: a meta-analysis. Pancreatology. 2013;13:48-57.

16. Orell SR. Pitfalls in fine needle aspiration cytology. Cytopathology. 2003;14:173-82.

17. Woolf KMW, Liang H, Sletten ZJ, et al. False-negative rate of endoscopic ultrasound-guided fine-needle aspiration for pancreatic solid and cystic lesions with matched surgical resections as the gold standard. Cancer Cytopathology. 2013;121:449-58.

18. Dietrich CF, Annema JT, Clementsen P, et al. Ultrasound techniques in the evaluation of the mediastinum, part I: endoscopic ultrasound (EUS), endobronchial ultrasound (EBUS) and transcutaneous mediastinal ultrasound (TMUS), introduction into ultrasound techniques. J Thorac Dis. 2015;7:E311-25.

19. Tournoy KG, Praet MM, Van Maele G, et al. Esophageal endoscopic ultrasound with fine-needle aspiration with an onsite cytopathologist: high accuracy for the diagnosis of mediastinal lymphadenopathy. Chest. 2005;128:3004-9.

20. Săftoiu A, Vilmann P, Guldhammer Skov B, et al. Endoscopic ultrasound (EUS)-guided trucut biopsy adds significant information to EUS-guided fine-needle aspiration in selected patients: a prospective study. Scand J Gastroenterol. 2007;42:117-25.

21. Jue TL, Sharaf RN, Appalaneni V, et al. Role of EUS for the evaluation of mediastinal adenopathy. Gastrointest Endosc. 2011;74:239-45.

22. Yasuda I, Goto N, Tsurumi H, et al. Endoscopic ultrasoundguided fine needle aspiration biopsy for diagnosis of lymphoproliferative disorders: feasibility of immunohistological, flow cytometric, and cytogenetic assessments. Am J Gastroenterol. 2012;107:397-404.

23. Al-Haddad M, Savabi MS, Sherman S, et al. Role of endoscopic ultrasound-guided fine-needle aspiration with flow cytometry to diagnose lymphoma: a single center experience. J Gastroenterol Hepatol (Aust). 2009;24:1826-33.

24. Mehra M, Tamhane A, Eloubeidi MA. EUS-guided FNA combined with flow cytometry in the diagnoses of suspected or recurrent intrathoracic or retroperitoneal lymphoma. Gastrointest Endosc. 2005;62:508-13.

25. Nakahara O, Yamao K, Bhatia V, et al. Usefulness of endoscopic ultrasound-guided fine needle aspiration (EUS-FNA) for undiagnosed intra-abdominal lymphadenopathy. J Gastroenterol. 2009;44:562-7.

26. Puli SR, Batapati Krishna Reddy J, Bechtold ML, et al. Endoscopic ultrasound: it's accuracy in evaluating mediastinal lymphadenopathy? A meta-analysis and systematic review. World J Gastroenterol. 2008;14:3028-37.

27. Bhutani MS. Transesophageal endoscopic ultrasound-guided mediastinal lymph node aspiration: does the end justify the means? Chest. 2000;117:298-301.

28. Vilmann P, Clementsen PF, Colella S, et al. Combined endobronchial and oesophageal endosonography for the diagnosis and staging of lung cancer. European society of gastrointestinal endoscopy (ESGE) guideline, in cooperation with the european respiratory society (ERS) and the European society of thoracic surgeons (ESTS). Euro Respir J. 2015;46:40-60.

29. Yamabe A, Irisawa A, Bhutani MS, et al. Usefulness of endoscopic ultrasound-guided fine-needle aspiration with a forwardviewing and curved linear-array echoendoscope for small gastrointestinal subepithelial lesions. Endosc Int Open. 2015;3:E161-4.

30. Puli SR, Reddy JB, Bechtold ML, et al. Staging accuracy of esophageal cancer by endoscopic ultrasound: a meta-analysis and systematic review. World J Gastroenterol. 2008;14:1479-90.

31. TenBerge J, Hoffman BJ, Hawes RH, et al. EUS-guided fine needle aspiration of the liver: indications, yield, and safety based on an international survey of 167 cases. Gastrointestinal Endosc. 2002;55:859-62.

32. Jani BS, Rzouq F, Saligram S, et al. Endoscopic Ultrasoundguided fine-needle aspiration of pancreatic lesions: a systematic review of technical and procedural variables. North Am J Med Sci. 2016;8:1-11.

33. Eisen GM, Dominitz JA, Faigel DO, et al. Guidelines for credentialing and granting privileges for endoscopic ultrasound. Gastrointest Endosc. 2001;54:811-4.

34. Shahidi N, Ou G, Lam E, et al. When trainees reach competency in performing endoscopic ultrasound: a systematic review. Endosc Int Open. 2017;5:E239-e243.

35. Weston BR, Bhutani MS. Optimizing diagnostic yield for EUSguided sampling of solid pancreatic lesions: a technical review. Gastroenterol Hepatol. 2013;9:352-63.

36. Gimeno-Garcia AZ, Elwassief A, Paquin SC, et al. Endoscopic ultrasound-guided fine needle aspiration cytology and biopsy in the evaluation of lymphoma. Endosc Ultrasound. 2012;1:17-22.

37. Carrara S, Anderloni A, Jovani M, et al. A prospective randomized study comparing $25-\mathrm{G}$ and $22-\mathrm{G}$ needles of a new platform for endoscopic ultrasound-guided fine needle aspiration of solid masses. Dig Liver Dis. 2016;48:49-54.

38. Camellini L, Carlinfante G, Azzolini F, et al. A randomized clinical trial comparing $22 \mathrm{G}$ and $25 \mathrm{G}$ needles in endoscopic ultrasound-guided fine-needle aspiration of solid lesions. Endoscopy. 2011;43:709-15.

39. Vilmann P, Saftoiu A, Hollerbach S, et al. Multicenter randomized controlled trial comparing the performance of 22 gauge versus 25 gauge EUS-FNA needles in solid masses. Scand J Gastroenterol. 2013;48:877-83.

40. Lee JH, Stewart J, Ross WA, et al. Blinded prospective comparison of the performance of 22-gauge and 25-gauge needles in endoscopic ultrasound-guided fine needle aspiration of the pancreas and peri-pancreatic lesions. Dig Dis Sci. 2009;54:2274-81.

41. Siddiqui UD, Rossi F, Rosenthal LS, et al. EUS-guided FNA of solid pancreatic masses: a prospective, randomized trial comparing 22-gauge and 25-gauge needles. Gastrointest Endosc. 2009;70:1093-7.

42. Yusuf TE, Ho S, Pavey DA, et al. Retrospective analysis of the utility of endoscopic ultrasound-guided fine-needle aspiration (EUS-FNA) in pancreatic masses, using a 22-gauge or 25-gauge needle system: a multicenter experience. Endoscopy. 2009;41:445-8.

43. Siddiqui AA, Lyles T, Avula H, et al. Endoscopic ultrasoundguided fine needle aspiration of pancreatic masses in a veteran population: comparison of results with 22- and 25-gauge needles. Pancreas. 2010;39:685-6.

44. Camellini L, Carlinfante G, Azzolini F, et al. A randomized clinical trial comparing $22 \mathrm{G}$ and $25 \mathrm{G}$ needles in endoscopic ultrasound-guided fine-needle aspiration of solid lesions. Endoscopy. 2011;43:709-15.

45. Uehara H, Ikezawa K, Kawada N, et al. Diagnostic accuracy of endoscopic ultrasound-guided fine needle aspiration for suspected pancreatic malignancy in relation to the size of lesions. J Gastroenterol Hepatol (Aust). 2011;26:1256-61.

46. Madhoun MF, Wani SB, Rastogi A, et al. The diagnostic accuracy of 22-gauge and 25-gauge needles in endoscopic ultrasound-guided fine needle aspiration of solid pancreatic lesions: a meta-analysis. Endoscopy. 2013;45:86-92.

47. Affolter KE, Schmidt RL, Matynia AP, et al. Needle size has only a limited effect on outcomes in EUS-guided fine needle 
aspiration: a systematic review and meta-analysis. Dig Dis Sci. 2013;58:1026-34.

48. Song TJ, Kim JH, Lee SS, et al. The prospective randomized, controlled trial of endoscopic ultrasound-guided fine-needle aspiration using $22 \mathrm{G}$ and $19 \mathrm{G}$ aspiration needles for solid pancreatic or peripancreatic masses. Am J Gastroenterol. 2010;105:1739-45.

49. Itoi T, Itokawa F, Sofuni A, et al. Puncture of solid pancreatic tumors guided by endoscopic ultrasonography: a pilot study series comparing trucut and 19-gauge and 22-gauge aspiration needles. Endoscopy. 2005;37:362-6.

50. Hasan M, Ramesh J, Bang JY, et al. 100 multi-center randomized trial comparing the $19 \mathrm{G}$ and $25 \mathrm{G}$ needles for EUS-guided FNA of large solid pancreatic mass lesions. Gastrointest Endosc. 2014;9(5, Supplement):AB112.

51. Wang K-X, Ben Q-W, Jin Z-D, et al. Assessment of morbidity and mortality associated with EUS-guided FNA: a systematic review. Gastrointest Endosc. 2011;73:283-90.

52. Gress F, Michael H, Gelrud D, et al. EUS-guided fine-needle aspiration of the pancreas: evaluation of pancreatitis as a complication. Gastrointest Endosc. 2002;56:864-7.

53. Sakamoto H, Kitano M, Komaki T, et al. Prospective comparative study of the EUS guided 25-gauge FNA needle with the 19-gauge Trucut needle and 22-gauge FNA needle in patients with solid pancreatic masses. J Gastroenterol Hepatol (Aust). 2009;24:384-90.

54. Gerke H, Rizk MK, Vanderheyden AD, et al. Randomized study comparing endoscopic ultrasound-guided Trucut biopsy and fine needle aspiration with high suction. Cytopathology. 2010;21:44-51.

55. Varadarajulu S, Fraig M, Schmulewitz N, et al. Comparison of EUS-guided 19-gauge trucut needle biopsy with EUS-guided fine-needle aspiration. Endoscopy. 2004;36:397-401.

56. Wittmann J, Kocjan G, Sgouros SN, et al. Endoscopic ultrasound-guided tissue sampling by combined fine needle aspiration and trucut needle biopsy: a prospective study. Cytopathology. 2006;17:27-33.

57. Larghi A, Verna EC, Stavropoulos SN, et al. EUS-guided trucut needle biopsies in patients with solid pancreatic masses: a prospective study. Gastrointest Endosc. 2004;59:185-90.

58. Aithal GP, Anagnostropoulos GK, Tam W, et al. EUS-guided tissue sampling: comparison of "dual sampling" (trucut biopsy plus FNA) with "sequential sampling" (trucut biopsy and then FNA as required). Endoscopy. 2007;39:725-30.

59. Berger LPV, Scheffer RCH, Weusten BLAM, et al. The additional value of EUS-guided Tru-cut biopsy to EUS-guided FNA in patients with mediastinal lesions. Gastrointest Endosc. 2009;69:1045-51.

60. Cho CM, Al-Haddad M, LeBlanc JK, et al. Rescue Endoscopic Ultrasound (EUS)-guided trucut biopsy following suboptimal EUS-guided fine needle aspiration for mediastinal lesions. Gut and Liver. 2013;7:150-6.

61. Dewitt J, Emerson RE, Sherman S, et al. Endoscopic ultrasoundguided trucut biopsy of gastrointestinal mesenchymal tumor. Surg Endosc Other Interv Tech. 2011;25:2192-202.

62. Ginès A, Wiersema MJ, Clain JE, et al. Prospective study of a trucut needle for performing EUS-guided biopsy with EUSguided FNA rescue. Gastrointest Endosc. 2005;62:597-601.

63. Ribeiro A, Pereira D, Escalón MP, et al. EUS-guided biopsy for the diagnosis and classification of lymphoma. Gastrointest Endosc. 2010;71:851-5.

64. Yun SS, Remotti H, Vazquez MF, et al. Endoscopic ultrasoundguided biopsies of pancreatic masses: comparison between fine needle aspirations and needle core biopsies. Diagn Cytopathol. 2007;35:276-82.
65. Alatawi A, Beuvon F, Grabar S, et al. Comparison of $22 \mathrm{G}$ reverse-beveled versus standard needle for endoscopic ultrasound-guided sampling of solid pancreatic lesions. United Euro Gastroenterol J. 2015;3:343-52.

66. Kim GH, Cho YK, Kim EY, et al. Comparison of 22-gauge aspiration needle with 22-gauge biopsy needle in endoscopic ultrasonography-guided subepithelial tumor sampling. Scand J Gastroenterol. 2014;49:347-54.

67. Bang JY, Hawes R, Varadarajulu S. A meta-analysis comparing ProCore and standard fine-needle aspiration needles for endoscopic ultrasound-guided tissue acquisition. Endoscopy. 2016;48:339-49.

68. Rodrigues-Pinto E, Jalaj S, Grimm IS, et al. Impact of EUSguided fine-needle biopsy sampling with a new core needle on the need for onsite cytopathologic assessment: a preliminary study. Gastrointest Endosc. 2016;84:1040-6.

69. Kandel P, Tranesh G, Nassar A, et al. EUS-guided fine needle biopsy sampling using a novel fork-tip needle: a case-control study. Gastrointest Endosc. 2016;84:1034-9.

70. Nayar MK, Paranandi B, Dawwas MF, et al. Comparison of the diagnostic performance of 2 core biopsy needles for EUS-guided tissue acquisition from solid pancreatic lesions. Gastrointest Endosc. 2017;85:1017-24.

71. Bang JY, Hebert-Magee S, Hasan MK, et al. Endoscopic ultrasonography-guided biopsy using a Franseen needle design: initial assessment. Dig Endosc. 2017;29:338-46.

72. El H II, Wu H, Reuss S, et al. Prospective assessment of the performance of a new fine needle biopsy device for EUS-guided sampling of solid lesions. Clinical Endosc. 2018;51:576.

73. Bang JY, Hebert-Magee S, Navaneethan U, et al. Randomized trial comparing the Franseen and Fork-tip needles for EUSguided fine-needle biopsy sampling of solid pancreatic mass lesions. Gastrointest Endosc. 2018;87:1432-8.

74. Bang JY, Hebert-Magee S, Navaneethan U, et al. Randomized trial comparing the franseen and fork-tip needles for EUS-guided fine-needle biopsy sampling of solid pancreatic mass lesions. Gastrointest Endosc. 2018;87:1432-8.

75. Al-Haddad M. Fine-needle biopsy sampling under EUS guidance: is one needle tip really better than the other? Gastrointest Endosc. 2018;87:1163.

76. Iglesias-Garcia J, Dominguez-Munoz JE, Abdulkader I, et al. Influence of on-site cytopathology evaluation on the diagnostic accuracy of endoscopic ultrasound-guided fine needle aspiration (EUS-FNA) of solid pancreatic masses. Am J Gastroenterol. 2011;106:1705-10.

77. Wani S, Mullady D, Early DS, et al. The clinical impact of immediate on-site cytopathology evaluation during endoscopic ultrasound-guided fine needle aspiration of pancreatic masses: a prospective multicenter randomized controlled trial. Am J Gastroenterol. 2015;110:1429.

78. Aadam AA, Wani S, Amick A, et al. A randomized controlled cross-over trial and cost analysis comparing endoscopic ultrasound fine needle aspiration and fine needle biopsy. Endosc Int Open. 2016;4:E497-505.

79. Rodrigues-Pinto E, Jalaj S, Grimm IS, et al. Impact of EUSguided fine-needle biopsy sampling with a new core needle on the need for onsite cytopathologic assessment: a preliminary study. Gastrointest Endosc. 2016;84:1040-6.

80. Fabbri C, Fuccio L, Fornelli A, et al. The presence of rapid onsite evaluation did not increase the adequacy and diagnostic accuracy of endoscopic ultrasound-guided tissue acquisition of solid pancreatic lesions with core needle. Surg Endosc. 2017;31:225-30.

81. Schmidt RL, Witt BL, Matynia AP, et al. Rapid on-site evaluation increases endoscopic ultrasound-guided fine-needle 
aspiration adequacy for pancreatic lesions. Dig Dis Sci. 2013;58:872-82.

82. Wani S, Early D, Kunkel J, et al. Diagnostic yield of malignancy during EUS-guided FNA of solid lesions with and without a stylet: a prospective, single blind, randomized, controlled trial. Gastrointest Endosc. 2012;76:328-35.

83. Kim JH, Park SW, Kim MK, et al. Meta-analysis for cytopathological outcomes in endoscopic ultrasonography-guided fine-needle aspiration with and without the stylet. Dig Dis Sci. 2016;61:2175-84.

84. Abe Y, Kawakami H, Oba K, et al. Effect of a stylet on a histological specimen in EUS-guided fine-needle tissue acquisition by using 22-gauge needles: a multicenter, prospective, randomized, controlled trial. Gastrointest Endosc. 2015;82(837-844):e831.

85. Lee JK, Choi JH, Lee KH, et al. A prospective, comparative trial to optimize sampling techniques in EUS-guided FNA of solid pancreatic masses. Gastrointest Endosc. 2013;77:745-51.

86. Kin T, Katanuma A, Yane K, et al. Diagnostic ability of EUSFNA for pancreatic solid lesions with conventional 22-gauge needle using the slow pull technique: a prospective study. Scand J Gastroenterol. 2015;50:900-7.

87. Attam R, Arain MA, Bloechl SJ, et al. "Wet suction technique (WEST)": a novel way to enhance the quality of EUS-FNA aspirate. Results of a prospective, single-blind, randomized, controlled trial using a 22-gauge needle for EUS-FNA of solid lesions. Gastrointest Endosc. 2015;81:1401-7.

88. Mennone A, Nathanson MH. Needle-based confocal laser endomicroscopy to assess liver histology in vivo. Gastrointest Endosc. 2011;73:338-44.

89. Becker V, Wallace MB, Fockens P, et al. Needle-based confocal endomicroscopy for in vivo histology of intra-abdominal organs: first results in a porcine model (with videos). Gastrointest Endosc. 2010;71:1260-6.

90. Giovannini M, Caillol F, Monges G, et al. Endoscopic ultrasound-guided needle-based confocal laser endomicroscopy in solid pancreatic masses. Endoscopy. 2016;48:892-8.

91. Kongkam P, Pittayanon R, Sampatanukul P, et al. Endoscopic ultrasound-guided needle-based confocal laser endomicroscopy for diagnosis of solid pancreatic lesions (ENES): a pilot study. Endosc Int Open. 2016;4:E17-23.

92. Konda VJA, Aslanian HR, Wallace MB, et al. First assessment of needle-based confocal laser endomicroscopy during EUSFNA procedures of the pancreas (with videos). Gastrointest Endosc. 2011;74:1049-60.

93. Karstensen JG, Cartana T, Constantinescu C, et al. Endoscopic ultrasound guided needle-based confocal laser endomicroscopy in solid pancreatic masses-a prospective validation study. Endosc Int Open. 2018;6:E78-85.

94. Bhutani MS, Koduru P, Joshi V, et al. EUS-guided needle-based confocal laser endomicroscopy: a novel technique with emerging applications. Gastroenterol Hepatol. 2015;11:235.

95. Chang KJ, Samarasena JB, Nakai Y, et al. Mo1502 endoscopic ultrasound (EUS) guided biopsy of the pancreas surface using a novel "through-the-needle" technique: can we biopsy the pancreas without trauma to the ducts? Gastrointest Endosc. 2013;77:AB405-6.

96. Nakai Y, Isayama $\mathrm{H}$, Chang KJ, et al. A pilot study of EUSguided through-the-needle forceps biopsy (with video). Gastrointest Endosc. 2016;84:158-62.

97. Shakhatreh MH, Naini SR, Brijbassie AA, et al. Use of a novel through-the-needle biopsy forceps in endoscopic ultrasound. Endosc Int Open. 2016;4:E439-42.

98. Kovacevic B, Karstensen JG, Havre RF, et al. Initial experience with EUS-guided microbiopsy forceps in diagnosing pancreatic cystic lesions: a multicenter feasibility study (with video). Endosc Ultrasound. 2018;7(6):383.

99. Wani S, Muthusamy VR, McGrath CM, et al. AGA white paper: optimizing endoscopic ultrasound-guided tissue acquisition and future directions. Clin Gastroenterol Hepatol. 2018;16:318-27.

100. Kandel P, Wallace MB. Advanced EUS guided tissue acquisition methods for pancreatic cancer. Cancers. 2018;10(2):54.

101. Wei S, Lieberman D, Morrissette JJ, et al. Using "residual" FNA rinse and body fluid specimens for next-generation sequencing: an institutional experience. Cancer Cytopathol. 2016;124:324-9.

102. Aisner DL, Rumery MD, Merrick DT, et al. Do more with less: tips and techniques for maximizing small biopsy and cytology specimens for molecular and ancillary testing: the university of Colorado experience. Arch Pathol lab Med. 2016;140(11):1206-20.

103. Roy-Chowdhuri S, Chen H, Singh RR, et al. Concurrent fine needle aspirations and core needle biopsies: a comparative study of substrates for next-generation sequencing in solid organ malignancies. Mod Pathol. 2017;30:499-508.

104. Rodriguez SA, Impey SD, Pelz C, et al. RNA sequencing distinguishes benign from malignant pancreatic lesions sampled by EUS-guided FNA. Gastrointest Endosc. 2016;84:252-8.

105. Roy-Chowdhuri S, Stewart J. Preanalytic variables in cytology: lessons learned from next-generation sequencing-the MD anderson experience. Arch Pathol Lab Med. 2016;140(11):1191-9.

106. Tiriac H, Bucobo JC, Tzimas D, et al. Successful creation of pancreatic cancer organoids by means of EUS-guided fineneedle biopsy sampling for personalized cancer treatment. Gastrointest Endosc. 2018;87:1474-80.

107. Lai Y, Wei X, Lin S, et al. Current status and perspectives of patient-derived xenograft models in cancer research. J Hematol Oncol. 2017;10:106.

108. Kim MP, Evans DB, Wang H, et al. Generation of orthotopic and heterotopic human pancreatic cancer xenografts in immunodeficient mice. Nat Protoc. 2009;4:1670-80.

109. Kandel P, Tranesh G, Nassar A, et al. EUS-guided fine needle biopsy sampling using a novel fork-tip needle: a case-control study. Gastrointest Endosc. 2016;84:1034-9.

110. Nayar MK, Paranandi B, Dawwas MF, et al. Comparison of the diagnostic performance of 2 core biopsy needles for EUS-guided tissue acquisition from solid pancreatic lesions. Gastrointest Endosc. 2017;85:1017-24.

111. Kandel P, Nassar A, Graddy C, et al. Mo1345 whole exome sequencing and genomic profiling of pancreas tumor tissue obtained with a novelfork-tipped eus guided fine needle core biopsy: a randomized controlled trial. Gastrointest Endosc. 2018:87:455-6.

112. Suzuki R, Thosani N, Annangi S, Guha S, Bhutani MS. Diagnostic yield of EUS-FNA-based cytology distinguishing malignant and benign IPMNs: a systematic review and meta-analysis. Pancreatol off $J$ Intern Assoc Pancreatol. (IAP) 2014;14(5):380-84.

113. Hebert-Magee S, Bae S, Varadarajulu S, et al. The presence of a cytopathologist increases the diagnostic accuracy of endoscopic ultrasound-guided fine needle aspiration cytology for pancreatic adenocarcinoma: a meta-analysis. Cytopathol off $\mathrm{J}$ Br Soc Clin Cytol. 2013;24(3):159-71.

114. Larghi A, Fuccio L, Chiarello G, et al. Fine-needle tissue acquisition from subepithelial lesions using a forward-viewing linear echoendoscope. Endoscopy. 2014;46(1):39-45.

115. Turhan N, Aydog G, Ozin Y, Cicek B, Kurt M, Oguz D. Endoscopic ultrasonography-guided fine-needle aspiration for diagnosing upper gastrointestinal submucosal lesions: a 
prospective study of 50 cases. Diagn Cytopathol. 2011;39(11):808-17.

116. Sadeghi A, Mohamadnejad M, Islami F, et al. Diagnostic yield of EUS-guided FNA for malignant biliary stricture: a systematic review and meta-analysis. Gastrointest Endosc. 2016;83(2):290-98.e291.

117. Navaneethan U, Njei B, Lourdusamy V, Konjeti R, Vargo JJ, Parsi MA. Comparative effectiveness of biliary brush cytology and intraductal biopsy for detection of malignant biliary strictures: a systematic review and meta-analysis. Gastrointest Endosc. 2015;81(1):168-76.

Publisher's Note Springer Nature remains neutral with regard to jurisdictional claims in published maps and institutional affiliations. 